\title{
119. Anticoagulant Peptide Obtained from Fibrinogen Degradation Products by Plasmin. II
}

\section{Sequence Determination of the Peptide}

\author{
By Akira TAKaki,*) Shinji Yoshitake, Masatsune IsHiguro, \\ and Masaru FunAtsu \\ Laboratory of Biochemistry, Faculty of Agriculture, \\ Kyushu University, Fukuoka \\ (Comm. by Yuzuru OKudA, M. J. A., Sept. 12, 1972)
}

In the previous paper, the isolation of an anticoagulant peptide from the fibrinogen degradation products by plasmin has been reported. The present paper deals with the determination of the amino acid sequence of the peptide.

Materials. Anticoagulant peptide of the bovine fibrinogen was prepared by the method described previously. $\left.{ }^{1}\right)$ Pepsin $(2 \times$ crystallized and lyophilized) was purchased from Sigma Chem. Co. Acid carboxypeptidase was kindly supplied by Dr. Eiji Ichishima from Enzymology Section of Tokyo Noko University, Tokyo, Japan.

Methods. Amino acid analysis. Amino acid analysis of the peptide was performed by the method of Spackman et al.2) with Hitachi automatic amino acid analyzer, Model KLA 3 B.

Edman degradation of the peptide..$^{3), 4)}$ The peptide was dissolved in $200 \mu \mathrm{l}$ of $50 \%$ pyridine, $\mathrm{pH} 9.3$, and $10 \mu \mathrm{l}$ of phenylisothiocyanate (PITC) was added. The tube was flushed with $\mathrm{N}_{2}$, stoppered and left at $40^{\circ} \mathrm{C}$ for 1 hour. Then the solution was dried in the dessicator at $60^{\circ} \mathrm{C}$. Cleavage was performed in $20 \mu \mathrm{l}$ of trifluoroacetic acid at $40^{\circ} \mathrm{C}$ for $20 \mathrm{~min}$. After removing trifluoroacetic acid in vacuo, $0.2 \mathrm{ml}$ of water was added to the residue. The thiazolinone derivative was extracted with ethyl acetate $(0.6 \mathrm{ml}, 2$ times $)$. The residual peptide in the aqueous phase was dried in vacuo over $\mathrm{P}_{2} \mathrm{O}_{5}$ and $\mathrm{NaOH}$ pellet, and then used for further degradation. The intermediate thiazolinone contained in the ethyl acetate phase was brought to dryness and converted to the phenylthiohydantoin derivative. The PTH-amino acid was identified by the thin layer chromatography on Silica Gel plate with either chloroform-methanol $(9: 1 \mathrm{v} / \mathrm{v})$ or $n$-heptane-ethylene chloride-propionic acid (45:25:17 v/v). The separation of PTH-glutamic acid and PTH-glutamine was performed with the latter developping system.

*) Present address: First Department of Surgery, Faculty of Medicine, Kyushu University, Fukuoka. 
Dansylation procedure. ${ }^{5)}$ The peptide was incubated at $40^{\circ} \mathrm{C}$ for 1 hour in a mixture of $20 \mu \mathrm{l}$ of $0.2 \mathrm{~N} \mathrm{NaHCO}_{3}$ and $20 \mu \mathrm{l}$ of DNSchloride (5-dimethylamino-1-naphthalenesulfonyl chloride) in acetone. The reaction mixture was dried and, after the addition of $50 \mu$ of $5.7 \mathrm{~N} \mathrm{HCl}$, the tube was evacuated and sealed. An overnight hydrolysis was carried out at $105^{\circ} \mathrm{C}$. After the hydrolysis was completed, the tube was opened and the $\mathrm{HCl}$ was removed in vacuo. The liberated DNS-amino acid was identified by thin layer chromatography on polyamide layer ${ }^{6)}$ with either water-formic acid (100:1.5 v/v) or benzene-glacial acetic acid $(9: 1 \mathrm{v} / \mathrm{v})$.

Peptic digestion of the peptide. $1.0 \mu$ mole of peptide was dissolved in $0.5 \mathrm{ml}$ of pepsin solution in $0.01 \mathrm{~N} \mathrm{HCl}$. The mixture was incubated at $37^{\circ} \mathrm{C}$ for 1 hour and then lyophilized. The digest was applied to the Dowex 50×2 (200-400 mesh) column $(0.9 \times 35 \mathrm{~cm})$ and eluted with a linear gradient from $0.2 \mathrm{M}$ pyridine-acetic acid buffer, $\mathrm{pH} 3.1$ to $2 \mathrm{M}$ pyridine-acetic acid buffer, $\mathrm{pH}$ 5.0. A flow rate of $16 \mathrm{ml} / \mathrm{hr}$ was maintained and each of $2.0 \mathrm{ml}$ fraction was collected.

Hydrolysis by acid carboxypeptidase. ${ }^{7)}$ The C-terminal analysis was carried out by digestion with acid carboxypeptidase at $30^{\circ} \mathrm{C}$, $\mathrm{pH}$ 3.1, and the liberated amino acid was analyzed by amino acid analyzer.

Results. Determination of terminal structure of the peptide. As reported previously, the amino acid composition of the active peptide was Ser 0.94, Glu 3.88, Pro 1.04, Ala 1.00, Leu 1.97 and Lys 1.03 by molar ratio. The subtractive Edman degradation revealed the N-terminal amino acid to be serine, and the specificity of plasmin required that lysine be the $\mathrm{C}$-terminal residue. The sequence of this peptide can be written to be Ser- $\left(\mathrm{Glu}_{4} \text {, Pro, Ala, Leu }\right)_{2}-\mathrm{Lys}$ by a single step of the Edman degradation.

Edman degradation of the peptide. The sequence of seven amino acid from the N-terminus was determined as Ser-Gln-Leu-Gln-GluAla-Pro-(Leu, Glu, Lys) by the thin layer chromatography of the PTH-amino acids. The yields of the PTH-amino acids were presented in Fig. 1. Dansylation method was also applied to the peptide after the fourth step of degradation to confirm the results of Edman degradation. The sequence of (Ser, Glu, Leu)-Glu-Glu-Ala-Pro-LeuGlu-Lys was determined by the thin layer chromatography of DNSamino acids.

Amino acid sequence of peptic digests of the peptide. The ionexchange chromatography on Dowex $50 \times 2$ separated two peptic peptides for Fr. 6-III-b (P-1 and P-2). P-1 had the composition of serine 0.81 , glutamic acid 1.00, and leucine 1.04, and P-2 had that of 


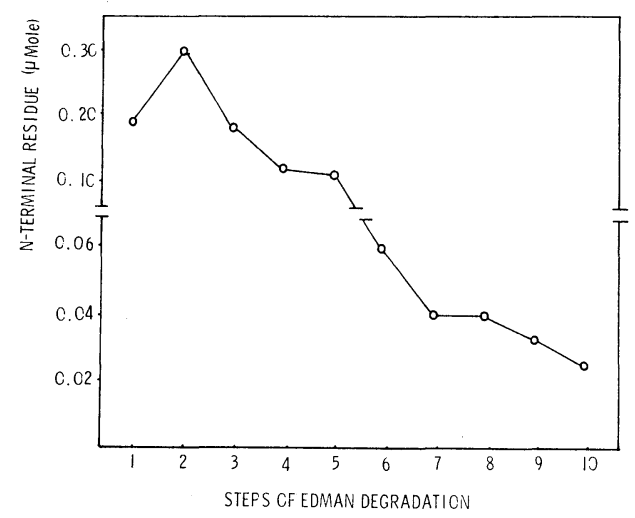

Fig. 1. Yield of N-terminal amino acids on sequential Edman degradation of 0.46 umole of peptide (6-III-b).

Table I. Amino acid composition of peptic and original peptides

\begin{tabular}{lcccccccc}
\hline & Lysine & Serine & $\begin{array}{c}\text { Glutamic } \\
\text { acid }\end{array}$ & Proline & Alanine Leucine & $\begin{array}{c}\text { Total } \\
\text { residues }\end{array}$ & $\begin{array}{c}\text { Yield } \\
(\%)\end{array}$ \\
\hline P-1 & & 0.81 & 1.00 & & & 1.04 & 3 & 75 \\
P-2 & 0.99 & & 2.92 & 1.00 & 1.00 & 1.16 & 7 & 55 \\
$\begin{array}{l}\text { Peptide } \\
\text { 6-III-b }\end{array}$ & 1.03 & 0.94 & 3.88 & 1.04 & 1.00 & 1.97 & & \\
\hline
\end{tabular}

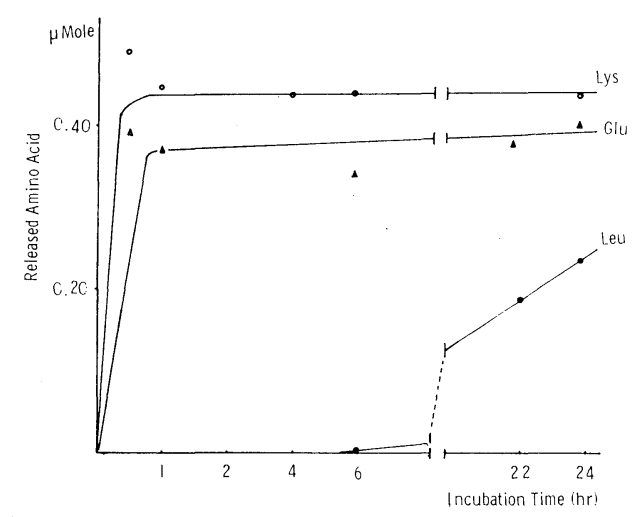

Fig. 2. Released amino acids from the peptide (6-III-b) by acid carboxypeptidase.

glutamic acid 2.92, proline 1.00, alanine 1.00, leucine 1.16 and lysine 0.99 (Table I).

Peptide P-1: Ser-Gln-Leu. This sequence was obtained by two steps of sequential Edman degradation and dansyl-Edman degradation. PTH-glutamine was identified as the second amino acid residue by the thin layer chromatography.

Peptide P-2: Gln-Glu-Ala-Pro-Leu-Glu-Lys. The sequence of 
this peptide was obtained by six steps of sequential Edman degradation with thin layer chromatography of PTH-amino acids on Silica Gel plate.

$C$-terminal amino acid analysis of the peptide. Acid carboxypeptidase digestion revealed the sequence of the C-terminus as (Ser, $\mathrm{Glu}_{3}$, Pro, Ala, Leu)-Leu-Glu-Lys (Fig. 2) .

From these results, the amino acid sequence of this peptide was determined to be as follows:

Ser-Gln-Leu-Gln-Glu-Ala-Pro-Leu-Glu-Lys.

Discussion. The general experimental approach during the sequence studies utilizing digestion with proteolytic enzyme, pepsin, and isolation of the arizing fragments by ion-exchange chromatography on Dowex $50 \times 2$ was used. Peptic digestion and ion-exchange chromatography were successively carried out, and the recovery of the peptic digests were $75 \%$ for $\mathrm{P}-1$ and $55 \%$ for P-2. The other fragments could not be detected by the ninhydrin method on the filter paper. From the results of amino acid analyses of the peptic peptides, P-1 was suspected to be derived from $\mathrm{N}$-terminal residue since it contained single serine residue, and P-2 from C-terminus since it contained single lysine residue (Table I). The N-terminal amino acid analyses of the peptic peptides revealed to be serine for P-1 and glutamine for P-2, respectively. From the specificity of the plasmin, lysine was positioned at the C-terminus of the original peptide, and thus peptic peptide sequence of (P-1)-(P-2) was indicated. This was confirmed by the sequence analyses of the peptic and original peptide. The sequence of the active peptide was determined to be

Ser-Gln-Leu-GIn-Glu-Ala-Pro-Leu-Glu-Lys.

Summary. The amino acid sequence of a decapeptide which had an inhibitory effect on the blood coagulation was determined by Edman degradation, dansyl-Edman procedure, and hydrolysis by acid carboxypeptidase. The amino acid sequence of this peptide was determined as follows:

Ser-Gln-Leu-Gln-Glu-Ala-Pro-Leu-Glu-Lys.

Acknowledgement. The authors wish to express their most sincere thanks to Professor Masaya Nishimura, Faculty of Medicine, Kyushu University, for his encouragements throughout this work. The authors wish to express their gratitude to Dr. Eiji Ichishima, the Enzymology Section of the Tokyo Noko University, for the kind donation of Acid Carboxypeptidase. 


\section{References}

1) Takaki, A., Ishiguro, M., and Funatsu, M.: Proc. Japan Acad., 48, 528-533 (1972).

2) Spackman, D. H., Stein, W. H., and Moor, S.: Anal. Chem., 30, 1190 (1958).

3) Edman, P.: Acta Chem. Scand., 10, 761 (1956).

4) Narita, K.: Kagaku to Seibutsu, 7, 670 (1969).

5) Gray, W. R.: Method in Enzymology. Academic Press, 11, p. 139 (1967).

6) Woods, K. W.: Biochim. Biophys. Acta, 133, 369 (1971).

7) Ichishima, E.: Biochim. Biophys. Acta, 258, 274 (1972). 